\title{
Loss of pleural fluid level postpneumonectomy
}

\author{
Stephen Lam
}

Department of General Surgery, James Paget Hospital, Great Yarmouth, UK

\section{Correspondence to}

Dr Stephen Lam,

stephenjosephlam@yahoo.co.uk

Accepted 25 November 2016

\section{DESCRIPTION}

A 73-year-old woman presented to a thoracic surgical clinic reporting of increased shortness of breath associated with a cough, productive of copious amounts of yellow stained fluid. She had undergone a right intrapericardial pneumonectomy 4 weeks previously for a T4N2M0 primary lung adenocarcinoma. The clinic chest X-ray demonstrated loss of the fluid level (figure 1) compared with a film taken 3 weeks previously (figure 2). A subsequent bronchoscopy demonstrated a bronchopleural fistula. She was admitted under a thoracic surgical team and underwent thoracotomy and bronchial stump repair using a muscle flap. The thoracotomy was not closed to allow packing of

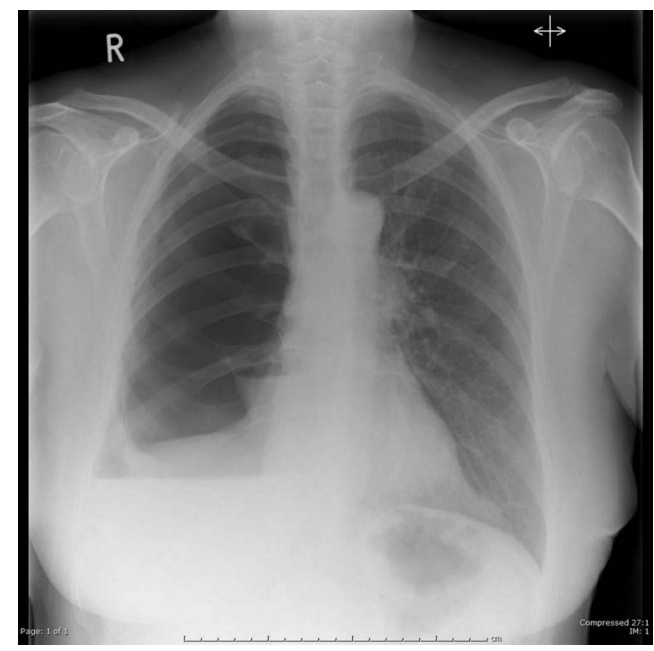

Figure 1 Chest X-ray showing some areas of basal opacity consistent with a small right-sided pleural effusion. A right pneumonectomy is noted.

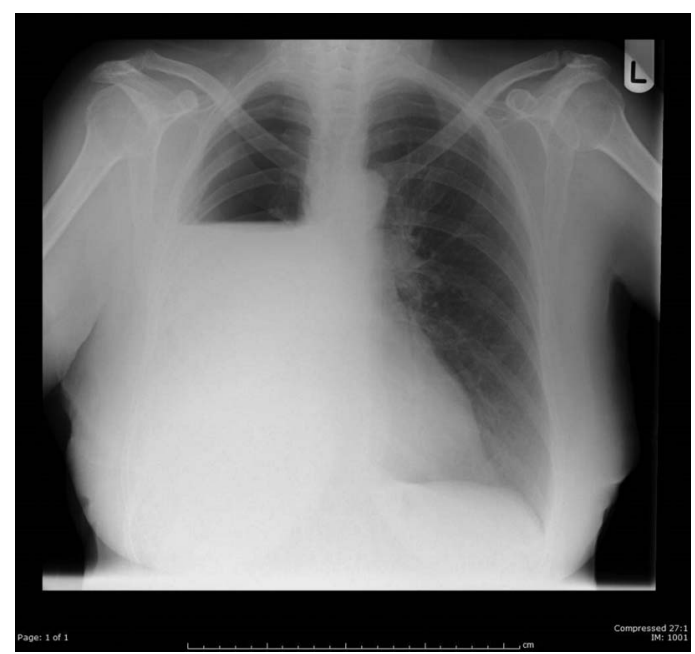

Figure 2 Chest X-ray showing a large right-sided opacity with a fluid level consistent with a pleural effusion secondary to a pneumonectomy.

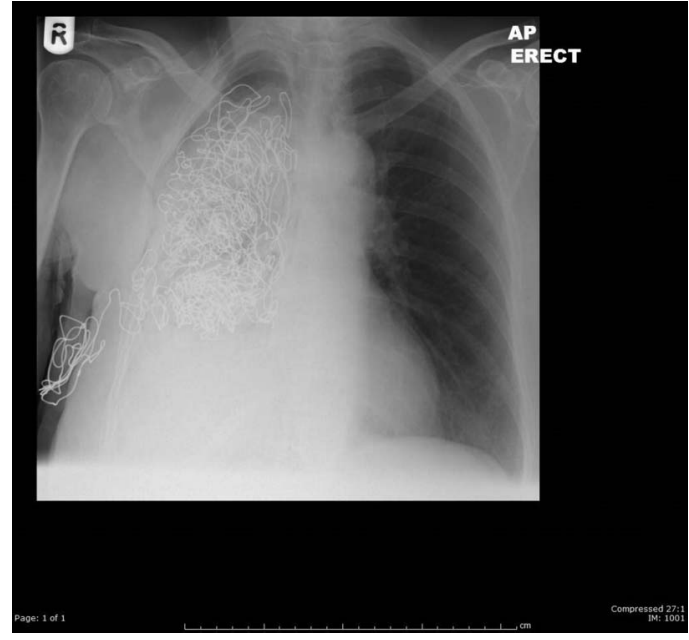

Figure 3 Chest X-ray showing surgical packing of the right thoracic space via a thoracostomy window.

the thoracic cavity with iodine soaked swabs (figure 3). She was discharged home 190 days later following closure of the thoracostomy window after three negative thoracic cavity swabs.

\section{Learning points}

A pleural effusion is anticipated after pneumonectomy due to fluid filling the thoracic cavity in place of the resected lung.

- In a patient who has undergone recent pneumonectomy, loss of the pleural fluid level (demonstrated on a plain chest X-ray) should raise the suspicion of a bronchopleural fistula (BPF).

- BPF often presents with a productive cough due to oral expulsion of pleural fluid-the fistula allows direct communication between the thoracic space and bronchus. Such a cough is often worse if the patient lies on the contralateral side (to the fistula) as this allows further drainage of residual fluid. ${ }^{1}$

- Empyema is usually associated with BPF due to contamination of bacterial flora from the bronchus into the usually aseptic pleural space. As such, treatment involves creation of a thoracostomy window and surgical packing of the thoracic space until pleural swabs are negative. $^{1-3}$

Acknowledgements The author thanks the patient for her agreement to present her clinical case.

Competing interests None declared.

Patient consent Obtained. 
Provenance and peer review Not commissioned; externally peer reviewed.

\section{REFERENCES}

1 Bayes AJ, Wilson JA, Chiu RC, et al. Clagett open-window thoracostomy in patients with empyema who had and had not undergone pneumonectomy. Can J Surg 1987;30:329-31.
2 Sarkar P, Chandak T, Shah R, et al. Diagnosis and management bronchopleural fistula. Indian J Chest Dis Allied Sci 2010;52:97-104.

3 Shamji FM, Ginsberg RJ, Cooper JD, et al. Open window thoracostomy in the management of postpneumonectomy empyema with or without bronchopleural fistula. J Thorac Cardiovasc Surg 1983;86:

818-22.

Copyright 2016 BMJ Publishing Group. All rights reserved. For permission to reuse any of this content visit http://group.bmj.com/group/rights-licensing/permissions.

BMJ Case Report Fellows may re-use this article for personal use and teaching without any further permission.

Become a Fellow of BMJ Case Reports today and you can:

- Submit as many cases as you like

- Enjoy fast sympathetic peer review and rapid publication of accepted articles

- Access all the published articles

- Re-use any of the published material for personal use and teaching without further permission

For information on Institutional Fellowships contact consortiasales@bmjgroup.com

Visit casereports.bmj.com for more articles like this and to become a Fellow 